Philosophie ANTIQUE

\section{Philosophie antique}

Problèmes, Renaissances, Usages

$20 \mid 2020$

Nouvelles figures de Socrate

Cinzia ARRUZZA \& Dmitri NiKULIN (éd.), Philosophy and Political Power in Antiquity

Leiden, Brill, 2016, 183 p., ISBN 978-90-04-32461-9

Juliette Lemaire

\title{
CpenEdition
}

Journals

Édition électronique

URL : https://journals.openedition.org/philosant/3501

DOI : 10.4000/philosant.3501

ISSN : 2648-2789

Éditeur

Éditions Vrin

\section{Édition imprimée}

Date de publication : 31 octobre 2020

Pagination : 300-303

ISBN : 978-2-7116-2977-0

ISSN : $1634-4561$

Référence électronique

Juliette Lemaire, "Cinzia arruzza \& Dmitri nikuıın (éd.), Philosophy and Political Power in Antiquity »,

Philosophie antique [En ligne], 20 | 2020, mis en ligne le 07 avril 2020, consulté le 05 décembre 2022

URL : http://journals.openedition.org/philosant/3501; DOI : https://doi.org/10.4000/philosant.3501

\section{(c) (i) (9)}

Creative Commons - Attribution - Pas d'Utilisation Commerciale - Pas de Modification 4.0 International - CC BY-NC-ND 4.0

https://creativecommons.org/licenses/by-nc-nd/4.0/ 
Le chapitre 5 (Selection of Testimonies: Evidence for the Function of Excerpts, p. 184-201) étudie les usages particuliers des sentences attribuées aux philosophes grecs, dans des traités dogmatiques ou des recueils de différents écrits philosophiques.

Le chapitre 6 est consacré au rôle du milieu alexandrin dans l'apparition des SPG (Philosophy of Soul: Some Characteristics of SPG, p. 202-220). Les SPG seraient nées d'une transformation de la paideia hellénistique en éducation destinée aux moines, où les exigences de la formation rhétorique classique cèdent la place à la « rhétorique de la crainte de Dieu ». L'origine de ce processus se situerait dans le milieu des philoponoi alexandrins, notamment dans l'activité de Sévère d'Antioche. YA identifie comme l'exemple par excellence de cette paideia nouvelle les Prophéties des philosophes païens connues aussi comme Théosophie de Tübingen. Dans les deux collections, YA décèle la même « intention apologétique ».

La seconde partie du livre contient le texte et la traduction anglaise des SPG (p. 231-325). La collection est divisée en soixante-dix-neuf sentences (maxims) et 64 conseils (counsels). À cette division - étayée déjà par la manière dont les $S P G$ sont transmises dans les manuscrits - YA apporte une justification supplémentaire, en citant comme exemple la doxographie de Stobée, divisée en short maxims and longer fragments exerpted from classical works (p. 62). Cette comparaison mériterait un examen supplémentaire, car la réception de la philosophie grecque en syriaque cache encore bien des énigmes.

Izabela JURASZ

Centre Léon Robin UMR 8061

CinziaArruzza \&DmitriNikulin (éd.), Philosophy and Political Power in Antiquity Leiden, Brill, 2016, 183 p., ISBN 978-90-04-32461-9.

Ce volume collectif traite des relations entre philosophie et pouvoir politique dans l'Antiquité, des sophistes jusqu'aux néoplatoniciens, dans huit contributions issues pour la plupart du Hannah Arendt and Reiner Schürmann Symposium in Political Philosophy - Tyrants, Kings, Emperors, and Philosophers: Philosophy and Political Power in Antiquity à la New School for Social Research à New York en mai 2013. Les éditeurs rappellent dans l'introduction l'invention de la philosophie politique par les Grecs, ainsi que la tension entre vita contemplativa et vita activa.

Dans sa contribution foisonnante « The Power of Speech : The Influence of the Sophists on Greek Politics », G. Giorgini rappelle l'apport majeur des sophistes dans la thématisation de l'opposition entre juste par nature et juste par convention, à travers l'étude de Protagoras. En dépit d'un parallèle bien venu entre le mythe de Protagoras (Platon, Protagoras, 320c-323a) et le texte hippocratique exposant l'origine de la médecine (Hippocrate, De l'ancienne médecine), G. Giorgini propose une lecture naturaliste du mythe de Protagoras qui nous semble prêter à confusion. Certes Protagoras est un partisan de la démocratie, mais prétendre que pour Protagoras tout être humain est doté par nature de respect et justice, et, partant, de la potentialité pour la vertu qui doit être cultivée par l'éducation, et que, par conséquent, l'art politique et la démocratie sont naturels, témoigne d'une lecture faussée du mythe de Protagoras dans lequel l'humain est en effet l'oublié de la nature. Faisant suite au vol du feu par Prométhée et à la menace de disparition des humains pourtant dotés de techniques, seul le don aux humains par Zeus des conditions de l'art politique leur permettra de vivre en cité. G. Giorgini s'intéresse ensuite à Gorgias et achève son parcours avec Antiphon, Critias et Thucydide. 
Dans «Philosophical Dogs and Tyrannical Wolves in Plato’s Republic », C. Arruzza insiste à propos de la République de Platon sur le rôle de l'éducation dans la réalisation de la bonne nature du philosophe qui, si elle n'est pas cultivée correctement, engendrera un tyran. La cité peut corrompre la bonne nature philosophique, telle Athènes avec Alcibiade dont le fantôme hante la République. Seul le tyran a un eros aussi puissant que le philosophe, si bien que le tyran est un philosophe manqué. Faisant du tyran un chien qui a perdu sa domesticité, C. Arruzza développe un thème bien connu des platoniciens.

Ch. Bobonich dans « What's the Good of Knowing the Forms ? » renouvelle la question de l'utilité de la connaissance des Formes en la reliant à l'établissement des lois et habitudes de justice, et à la formation des caractères des citoyens. Les philosophes capables de voir les limites et manques des conceptions populaires de lajustice voient mieux que les autres dans la caverne. Mais la connaissance des Formes est parfois insuffisante, par exemple pour reconnaître et calculer le nombre nuptial pour les unions sexuelles favorisant l'engendrement de bons naturels. Autre insuffisance : la connaissance d'une Forme ne permet pas de connaître toutes les propriétés de la chose qui participe à cette forme. Finalement le philosophe, outre la connaissance des Formes, a besoin d'expérience.

Dans « Individual competence and Collective Deliberation in Aristotle's Politics » Ch. Horn se demande si Aristote défend un gouvernement par les experts ou par la multitude. Dans Politiques III, 15 est évoquée une supériorité morale de la multitude avec «l'argument cumulatif ». Pourtant Aristote n'est pas un défenseur acharné de la démocratie et semble vouloir préserver les constitutions existantes sans laisser place à la résistance à l'oppression ou à la désobéissance civile (voir Pol.III, 15 et IV, 4). La multitude n'est supérieure que dans les cas non prévus par la loi. L'argument cumulatif est-il une justification « avant la lettre » de la démocratie délibérative, comme J. Waldron («The Wisdom of Multitude », 1995) l'a soutenu ? Contrairement à Protagoras qui soutient que la vertu politique appartient à tous et que tous peuvent donc participer aux affaires publiques, Aristote soutient que chacun a sa compétence spécifique et doit participer au jugement collectif par sa contribution individuelle. L'argument cumulatif ne concerne donc pas la question du meilleur pour la cité mais constitue un moyen pour trouver une solution à des problèmes techniques. Aristote défend un principe finalement assez platonicien de compétence politique ouverte selon lequel l'ordre politique établi doit s'approcher le plus possible de la raison philosophique.

Selon D. Nikulin dans « Diogenes the Comic, or How to Tell the Truth in the Face of a Tyrant », Diogène de Sinope inaugure une nouvelle politique en se qualifiant de

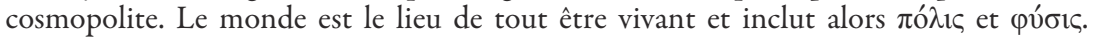
Diogène sans abri n'a pas de vie privée. Sa maison est le monde entier, c'est pourquoi il

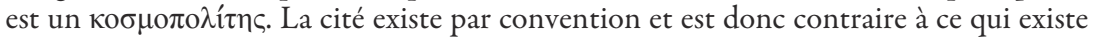
par nature. Le seul moyen de bien vivre est de retourner à la nature contre la convention contre nature, pour revenir au sens premier de la vie bonne fourni par la nature alors même que l'on reste dans la cité. Le cynique vit de la décomposition physique et morale

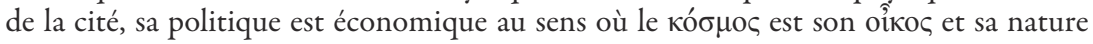
domestiquée. Ce que Diogène vise ultimement est sa liberté personnelle en tant qu'autosuffisance, c'est-à-dire la réalisation de la vie bonne ; d'abord libération négative de l'oppression dans l'absence de honte qui se transforme ensuite en liberté positive, la liberté du discours dans la $\pi \alpha \rho \rho \eta \sigma i ́ \alpha$. Le projet politique de Diogène est une critique puissante des institutions morales et politiques où la libération de soi-même devient la précondition de la libération de tous.

G. Reydams-Schils dans « Dio of Prusa and the Roman Stoics on How to Speak the Truth to Oneself and to Power » revient sur le thème de la responsabilité politique dans 


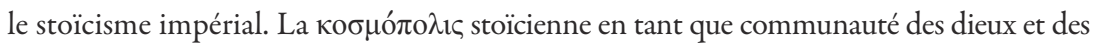
sages demeure toujours à l'arrière-plan de l'action politique stö̈cienne dont le modèle reste l'opposition du Sénat à l'Empereur romain. Or Dion de Pruse et Marc Aurèle montrent que la responsabilité politique ne signifie pas seulement agir hérö̈quement en temps de crise. Prolongement du « Connais-toi toi-même », la $\pi \alpha \rho \rho \eta \sigma i ́ \alpha$ selon Dion de Pruse signifie qu'avant de gouverner les autres, on doit être capable de se gouverner soi-même. Le courage politique pour les stoïciens romains ne consiste pas seulement à ne pas être intimidé par le pouvoir absolu, ni à s'engager dans les moments de crise mais bien à conserver chaque jour un souci social constant.

E. Spinelli dans « Stoic Utopia Reconsidered : Pyrrhonism, Ethics and Politics » rappelle que dans Contre les moralistes Sextus entend démolir les promesses vaines de ses adversaires dogmatiques. En $M$. XI, Sextus s'attache à la notion d'art de vivre, particulièrement développée par les stoïciens. E. Spinelli reconstruit un schéma syllogistique de la section $M$. XI 188-196: chaque art ou science s'identifie sur la base du travail qui s'accomplit selon un critère technique ou scientifique; l'art de vivre stoïcien ne s'enracine dans aucune activité spécifique ; donc il n'y a pas d'art de vivre stoïcien. Sextus accompagne son argument de citations choquantes de Zénon et Chrysippe probablement recueillies par le sceptique Cassius à propos de relations sexuelles en tout genre, de l'inceste et du cannibalisme. Ces citations exhibent le caractère antisocial et antipolitique des stoïciens, contre les normes imposées par la vie de tous les jours. Ainsi le dixième mode d'Énésidème sur l'action ne constitue pas une position relativiste sur les valeurs mais conduit à une suspension du jugement quant aux valeurs morales. Le sceptique règle sa conduite sur ce qui couramment apparaît être bon ou mauvais à l'aide d'une machine antidogmatique: non plus la force abstraite des arguments philosophiques

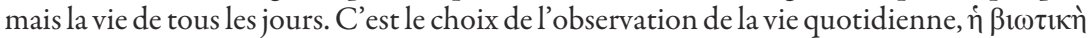

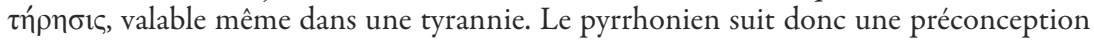
innée, antérieure logiquement et chronologiquement à toute action morale, résultant d'un engagement empirique dans les habitudes, lois et coutumes d'un pays.

D. J. O’Meara dans « Plato's Tyrant in Neoplatonic Philosophy » s'intéresse d'abord à la manière dont les néoplatoniciens tardifs ont considéré la nature et les origines de la tyrannie dans le contexte de leur lecture de Platon, puis à la manière dont ils ont utilisé Platon pour décrire et analyser les réalités politiques de leur temps. Le tyran platonicien leur fournit des outils conceptuels pour diagnostiquer le mal apporté par les empereurs de cette période. D. J. O'Meara note que c'est à propos du mythe d'Er et donc dans un contexte eschatologique que l'on trouve les remarques de Proclus sur le tyran. Est examinée d'abord la vie tyrannique de l'âme, celle où règne le maximum d'injustice. Par différence, l'âme gouvernée par la raison est la vie philosophique, c'est-àdire royale. Proclus oppose régime tyrannique et royauté. Les tyrans sont les ennemis des lois issues des lois cosmiques, leurs crimes vont donc aussi contre les lois cosmiques et le sacré. C'est pourquoi ils subissent la plus grande punition dans le mythe d'Er : ils sont coupables d'impiété. Proclus n'a pas subi de persécutions, mais sous l'Empereur Justinien, la vie devint beaucoup plus difficile : Damascius dut s'exiler en Perse avec collègues et élèves dont Simplicius. À leur retour, ils durent limiter leurs activités d'enseignement. Dans sa Vie d'Isidore Damascius utilise le schème de la dégradation des régimes politiques de la République VIII et IX, le combinant avec le mythe de l'âge d'or pour décrire la période actuelle comme celle du règne du désir, adaptant ce schème à partir d'un passé mythique et historique jusqu'à un présent bien réel et décrit comme tyrannique. Simplicius dans son Commentaire au Manuel d'Epictète ferait allusion au régime tyrannique de Justinien.

Cet ouvrage propose des analyses variées des relations entre philosophie et pouvoir 
politique dans l'Antiquité selon les écoles ou courants philosophiques majeurs, à l'exception notable des épicuriens. Certaines de ces contributions mériteraient une note critique plus développée. L'ouvrage quant à lui s'adresse assurément à tous ceux auxquels les liens entre philosophie et politique antiques importent.

Juliette LEMAIRE

Centre Jean Pépin UMR8230 CNRS-ENS-PSL

Gwenaëlle Aubry, Genèse du Dieu souverain. Archéologie de la puissance II. Paris, Librairie philosophique J. Vrin, 2018 (Bibliothèque d'histoire de la philosophie), 320 p., ISBN 978-2-7116-2806-3.

The present volume is the successor to Dieu sans la puissance. Dunamisetenergeiachez Aristote et chez Plotin (Paris, Vrin, 2006). In that book, the author examines Aristotelian metaphysics as an ontology of act-potency (energeia-dunamis). Her conclusion is that the act that is the life of the unmoved mover is pure or complete actualization, which means that it has no further actualizations. In that case, the effect of the unmoved mover as first principle of all can only be as an ideal that is imitated by beings that can imitate it. She contrasts Aristotle's account of act as first principle with that of Plotinus who, following Plato, makes the first principle of all dunamis tön pantōn, where dunamis must be understood as power, not potency.

In the book considered here, Aubry continues her examination of how the PlatonicAristotelian background is developed within the Christian theology of the Middle Ages. She covers a vast amount of material, including Augustine, Peter Damian and Peter Abelard, Peter Lombard, Thomas Aquinas, and Duns Scotus. Her aim is to show how the all-powerful or omnipotent God of Christianity arises out of the Aristotelian pure act and how Christian philosophers worked out the idea of the all-powerful as an agent (p. 13). In the course of her introduction to the main body of expository chapters, Aubry presents a concise survey of the many problems surrounding the adaptation of PlatonicAristotelian metaphysics to the exigencies of Christian theology. Above all, assuming that God is omnipotent in some sense, he then has an unlimited will, for any limitation on that will would imply a limitation on omnipotence. Aubry contrasts "puissance de tout" (dunamis pantonn) with "toute-puissance," where the former is constrained at least by the good and the latter is not. The theology of a God who is omnipotent faces the problem of evil, although this is clearly also a problem for a theology of "puissance de tout." As Aubry acutely observes, the problem of the compatibility of omnipotence with other attributes of the divine-especially goodness-is independent of the problems of theodicy, even if the latter is ultimately derived from the former (p. 16). In addition, the problem of human freedom inevitably arises if God is truly omnipotent (p. 22). The concept of an omnipotent God is further distinguished from that of the Pantokrator, the God of potentia ordinata rather than potentia absoluta (p. 27). The Pantokrator is constrained by the good, even if this constraint is not viewed negatively; the omnipotent God is constrained by nothing. But this fact opens the way to a myriad of theological and philosophical issues.

The first chapter focuses on Augustine who, apart from Origen, is probably the first to try to bring together the God of scripture and the Platonic heritage. Three points stand out in Aubry's account. First, Augustine refuses to make goodness a criterion independent of God's omnipotence. How the apparently evil is nevertheless good must 